\title{
A microparametric approach on goal of motion constructions: properties of adpositional systems in Romance and Germanic*
}

\author{
Cristina Real Puigdollers \\ Universitat Autònoma de Barcelona. Centre de Lingüística Teòrica \\ 08193 Bellaterra (Barcelona). Spain
}

Received: April 22010

Accepted: October 142010

\begin{abstract}
This paper explores the idea that the properties of adpositional systems can suffice to explain the Talmian distinction between satellite and verb framed languages. Following the insight that morphological simple prepositions in Romance languages are only locative, I propose that the functional domain of the directional/path preposition is defective and, hence, has to be licensed via incorporation to the (motion) verb. Prepositional incorporation, understood as head movement, prevents manner incorporation, as a particular case of Kayne's (1994) condition on adjunction. The paper offers an account for Talmian lexicalization patterns from a non lexicalist perspective, reducing typological differences between languages to specific properties within the functional domain of lexical heads.
\end{abstract}

Key words: prepositions, satellite framed, verb framed, Romance languages, Germanic languages, lexicon.

\section{Table of Contents}

1. Theoretical framework

2. The ESAH and the verb-framed/ satellite-framed distinction

3. An analysis of PPs in Romance and Germanic languages
4. Towards an analysis of the satellite-framed/verb-framed distinction

5. Conclusions

References

* I would like to thank Cedric Boeckx, Gemma Rigau and an anonymous reviewer for reading different versions of this paper, and giving helpful comments and discussion. I also want to thank Víctor Acedo and Txuss Martin for valuable discussion. Moreover I am very grateful to the audiences of the GLIF Seminars (UPF), Seminari del Centre de Lingüística Teòrica (UAB), and different seminars at Georgetown University, in which previous versions of this work were presented. I want to express my gratitude for data and judgments on the different examples used throughout the paper to Arlette Aubier, Kerry Burke, Gretel de Cuyper, Eddy Michaels and Henriette Wesselink. Finally I want to thank Kerry Burke and Eddy Michaels for proofreading and correcting different versions of this manuscript. Any errors or lapses are solely the author's responsibility. 
According to Talmy (2000) languages can be classified into two groups depending on where the path is lexicalized, in the verb or in a satellite of the verb. A classical example of verb-framed language is Spanish, and all Romance languages in general, because they lexicalize Path and Motion into the verb (1). In these languages, an inherent directional verb is required to convey directed motion, expressing optionally manner through adjunction (1)b. On the contrary, satellite-framed languages express manner and motion in the verb and path through a satellite (2).

(1) Spanish expressions of Motion with conflation of Path.

a. La botella entró a la cueva flotando the bottle moved-in to the cave (floating) 'the bottle floated into the cave'

b. La botella salió de la cueva flotando the bottle moved-out from the cave (floating) 'The bottle floated out of the cave'

c. *La botella flotó a la cueva the bottle floated to the cave

(2) Move+manner conflation patterns in English

a. The rock rolled down the hill

b. The bottle floated into the cave

(Talmy 2000)

Traditionally linguists have explained this distinction by exploring the semantic and syntactic properties of the verb. On the other hand, recent works have focused on the properties of the inventory of adpositions in different linguistic families (Folli 2002, Tungseth 2006, Fábregas 2007, Son 2007, Gehrke 2008). Specifically, some of them propose the idea that Romance languages behave as verb-framed languages because they lack pure directional prepositions, and therefore can only express path through the verb. In this work I argue that Romance simple prepositions are always locative because of the syntactic properties of PPs and VPs, and not as a mere property of the lexical inventory of adpositions in this linguistic family.

In this paper I explore some counterexamples to Talmy's classification. Thus, some verb-framed languages allow the expression of telic directed motion events with a subset of manner of motion verbs (see Folli 2002, Folli and Ramchand 2005, Zubizarreta and Oh 2007 for Italian; Jones (1983), Cummins (1996), Fong and Poulin (1998) for French). These examples will be explored in light of similar constructions found in Germanic Languages (4) (Dutch, English, Norwegian) (see den Dikken 2003, 2006, Gerhke 2008, Tungseth 2006).

(3) Gianni è corso a casa

(Italian)

Gianni is run to house

'Gianni has run into the house'

(4) The boy walked in the store

(English) 
My research follows a non-lexicalist approach to cross-linguistic variation, from a microparametric point of view (Borer 1984, Chomsky 1995): Talmian lexicalization patterns can be accounted for from a non-lexicalist perspective, and reduced to differences in the feature content associated with lexical heads.

The article is organized as follows: In section 1, I outline the framework adopted here. Section 2 discusses the syntactic behavior of ambiguous prepositions in both Germanic and Romance languages to examine whether counterexamples to Talmy's lexicalization patterns are really problematic. In section 3, I review the properties of these examples in Romance and Germanic and put forth an analysis of them. Section 4 states overall conclusions.

\section{Theoretical framework}

This paper pursues a "cartographic approach" to adpositions following a rich tradition of works such as van Riemsdijk (1978, 1990), Koopman (2000), den Dikken (2003, 2006, 2008), or Svenonius (2004, 2006). The majority of these proposals have explored the inner structure of Germanic PPs: Dutch (van Riemsdijk 1978, 1990; Koopman 2000; den Dikken 2003, 2006; Gehrke 2008), German (Gehrke, 2008; den Dikken 2003, 2006), Norwegian (Tungseth 2006), or English (Svenonius 2004). These works, to a greater or lesser extent, posit a rich functional domain within the internal structure of PPs. In this paper, I endorse den Dikken's (2003, 2006) theory of adpositions to analyze the structure of simple Romance PPs and determine their inner structure throughout the prepositional syntactic behavior and their semantic interpretation.

Cartographic approaches on prepositions are commonly based on the conceptual argument structure of PPs put forward by Jackendoff (1990) in which two basic semantic components are distinguished: Path and Place. According to this view, semantic labels such as Path and Place are compositionally and asymmetrically related. Thus, the argument structure of Path always contains a Place component, mirroring the morphological shape of English complex goal prepositions such as into or onto. This composite view of paths is generally adopted by cartographic approaches, in which these semantic predicates are conceived as syntactic heads, the asymmetry between Path and Place being then a consequence of syntactic structure. In den Dikken's approach these notions are labeled as $\mathrm{P}_{\mathrm{DIR}}$ and $\mathrm{P}_{\text {LOC }}$ (den Dikken op. cit.) and both categories can project selectively a rich functional PP on their own. Throughout the paper I will use the label of $\mathrm{P}_{\text {DIR }}$ and $\mathrm{P}_{\mathrm{LOC}}$ as the syntactic counterpart of the Path and Place semantic components, equivalent to the PATH and PLACE heads used in current cartographic approaches to PPs (e.g. Koopman 2000, Svenonius 2004, 2006). In this paper, I do not explore a deep semantic analysis of Ps and I will only consider that $\mathrm{P}_{\text {DIR }}$ and $\mathrm{P}_{\mathrm{LOC}}$ receive a Path and Place semantic interpretation, assuming a Jackendovian analysis of the argument structure of paths.

The analysis of Romance PPs developed here is indebted to two different works on Germanic PPs: den Dikken's (2003, 2006) theory on adpositions and Gehrke's (2008) work on the semantics and syntax of adpositions in West Germanic lan- 
guages. The latter work is focused on the different interpretations of PPs when they are part of a motion event. In this section I state the theoretical assumptions underlying the analysis that will be depicted in section 3: section 1.1 develops den Dikken's theory of Ps and finally, section 1.2 outlines Gehrke's (2008) main hypothesis from which the proposal endorsed here follows.

\subsection{Den Dikken's (2003, 2006) theory of adpositions}

Den Dikken's theory assumes that prepositions, both $\mathrm{P}_{\mathrm{DIR}}$ and $\mathrm{P}_{\mathrm{LOC}}$, are lexical categories that project a functional structure along with the nominal and verbal domain (see also van Riemsdijk 1990, Tortora 2008). This framework assumes a cartographic approach in which PPs have a rich functional structure where each functional layer is called up selectively. PPs can differ as to whether these functional projections are present or not: if they are present, PPs are full-fledged and complete, they are licensed within the PP domain, and they are movable (Koopman 2000); if they are not, these PPs are defective: the $\mathrm{P}_{\mathrm{DIR}}$ or $\mathrm{P}_{\mathrm{LOC}}$ category that is the head of the phrase needs to be licensed externally.

According to this approach, there are three functional heads, C, Dx and Asp, that can be present in the extended projection of any lexical head, and that are associated with different semantic interpretations depending in which lexical domain they appear. I refer the reader to den Dikken $(2003,2006)$ for a detailed account on the interpretation and the justification of these functional layers, since the presence or interpretation of them is not essential for the purposes of this paper.

Among the different structural possibilities for PPs, the relevant ones for the discussion are those in which there is a complete PP that projects a full-fledge functional structure, or a defective one in which the PP is bare. Below there is a summary of the possible PP structures that can be found in the complement position of the verb ${ }^{1}$ :

(5) Locative prepositions:
a. $\left[{ }_{\mathrm{CP}} \mathrm{C}^{[\mathrm{PLACE}]}\left[_{\mathrm{DxP}} \mathrm{Dx}^{[\mathrm{PLACE}]}\left[_{\mathrm{AspP}} \operatorname{Asp}^{[\mathrm{PLACE}]}{ }_{\mathrm{PP}} \mathrm{P}_{\mathrm{Loc}} \cdots\right]\right]\right]$
b. $\left[{ }_{\mathrm{PP}} \mathrm{P}_{\mathrm{Loc}} \cdots\right]$

(6) Directional prepositions:
a. $\left[{ }_{\mathrm{CP}} \mathrm{C}^{[\mathrm{PATH}]}\left[_{\mathrm{DxP}} \mathrm{Dx}^{[\mathrm{PATH}]}\left[_{\mathrm{AspP}} \mathrm{Asp}^{[\mathrm{PATH}]}\left[_{\mathrm{PP}} \mathrm{P}_{\mathrm{Dir}} \ldots\right]\right]\right]\right]$
b. $\left[{ }_{\mathrm{PP}} \mathrm{P}_{\mathrm{DIR}} \cdots\right]$

1. See den Dikken $(2003,2006)$ for a detailed description of the possible structures below and above $\mathrm{P}_{\mathrm{DIR}}$ and $\mathrm{P}_{\text {LOC }}$ I will not discuss the details of his approach here because they are not crucial to the account. What is important is the distinction between a defective PP and a full-fledged PP, both in the $\mathrm{P}_{\mathrm{DIR}}$ or in the $\mathrm{P}_{\mathrm{LOC}}$ domain. I will develop the implications of this distinction in section 3 below. Note that I have dismissed one possible structure (for den Dikken 2006 account there are finally five possibilities to consider in the verbal complement position): the one in which a full $\mathrm{P}_{\mathrm{DIR}}$ takes a semidefective $\mathrm{PP}_{\text {LOC }}$ (built up until $\mathrm{Dx}^{[\mathrm{PLACE}]} \mathrm{P}$ ), since this level of detail is not necessary for our interests. 
The defectiveness in the functional structure of PPs has consequences in their syntactic behavior. For example, as shown in Koopman (2000), constituents that project a complete functional structure are movable, while defective ones are not. Recall that bare $\mathrm{P}_{\mathrm{DIR}}$ in the complement position of the verb needs to incorporate into $\mathrm{V}$ to get licensed, if it does not get licensed by incorporation of the head below $\left(\mathrm{P}_{\mathrm{LOC}}\right.$, as in Dutch postpositions, see section 3).

\subsection{Gehrke's (2007, 2008) Structural Ambiguity Hypothesis}

According to Talmy's typology, Germanic languages are classified as satelliteframed languages since they lexicalize the Path into a satellite (a particle) or a PP in a directed motion event construction. Gehrke challenges this claim examining the behavior of certain West Germanic (English, Dutch and German) prepositions that are ambiguous depending on the type of verb they appear with, showing that Germanic languages do not always convey the path ${ }^{2}$ in the adpositional element. Gehrke outlines a hypothesis establishing that this ambiguity is systematic, predictable, and contextually derived: the Structural Ambiguity Hypothesis.

(7) The Structural Ambiguity Hypothesis (SAH, henceforth): the spatial Ps in, on, under, and behind are locative only. Any ambiguity between a directional and a locative meaning is structural, and not lexical. (Gehrke 2008: 88).

Gehrke restricts the SAH to just the above-mentioned prepositions and remains agnostic about the rest. ${ }^{3}$ She adds that prepositions such as $a$ in French that are systematically ambiguous between a locative and a directional reading cannot be covered by the SAH: "It seems impossible to derive the directional reading from the locative one, or vice versa" (Gerhke 2008:88). Contrary to what Gerhke assumes for Romance Ps, I put forth the idea that the SAH can also account for Romance Ps. The basic differences with the properties of Germanic ambiguous Ps should be looked up in the syntactic structure of the VP and the PP, and not in the inaccuracy of the SAH in Romance. For that reason, I refer to the SAH in this paper as the ESAH that I define as follows:

(8) The Extended Structural Ambiguity Hypothesis (ESAH): for any spatial preposition that can be interpreted as locative, it is only locative. Any ambiguity between a directional and a locative meaning is structural.

In the following section I review Gehrke's (2008) and Tungseth's (2006) data from West Germanic languages (Dutch and English), and Norwegian to see the

2. Specifically, the author appeals to the notion of goal, understood as a type of path, namely, a bounded path.

3. Gerhke (2007) proposes a stronger version of the SAH, that covers the set of all ambiguous prepositions. In this paper I aim to extend the SAH to Romance Languages as well (much more in the spirit of her earlier work). 
main differences that these ambiguous prepositions have with Romance prepositions.

\section{The ESAH and the verb-framed/satellite-framed distinction}

As noted in section 1, the ESAH states that the ambiguity of certain prepositions is provided by the specific syntactic context in which these prepositions appear. According to this hypothesis ambiguity is not lexical, but arises from context, which is in line with current non-projectionist perspective of lexical items, as the one endorsed here (see Borer 2005, or the different works on the Distributive Morphology framework, Marantz 1997, and subsequent works). Accordingly, prepositions are not polysemic, they only express a relationship of location, either locative or directional. In this section, I outline the behavior of ambiguous prepositions both in Germanic and Romance languages and review the conditions in which directional interpretations arise.

\subsection{Germanic Prepositions}

As has been observed, certain Germanic locative prepositions can derive goal of motion interpretations in the complement position of a subset of motion verbs (see den Dikken 2006, Gehrke 2008, Koopman 2000, Tungseth 2006). Following Svenonius (2004), an adposition is inherently locative if it can combine with a stative verb and convey a meaning of static location. The examples in (9) show that English prepositions such as in and on are inherently locative (9)a while complex prepositions in (9)b are not.

(9) a. The box stayed/remained in/on/under/behind the table

b. *The box stayed/remained into/onto the table

(from Gehrke 2008: 87)

Furthermore, locative adpositions express a static location even when the verb conveys a meaning of motion. However, with a certain class of motion verbs locative adpositions can have both a directional and a locative meaning. For instance, Dutch prepositions (inherently locative, see den Dikken 2003, 2006 or Gehrke 2008) allow a directional and a locative interpretation when combined with verbs like springen 'jump', while Dutch postpositions only allow for a directional reading.

(10) a. Jan sprong in de sloot Jan jumped the ditch

b. Jan sprong de sloot in Jan jumped in the ditch locative/directional

*locative/directional

(den Dikken 2003:5) 
By the ESAH, the meaning of these prepositions is inherently locative, and the source of the directional interpretation is structural. Thus, the fact that locative adpositions can have a directional reading in certain contexts has been attested for in several Germanic languages, such as in and on prepositions in English (e.g. (11) Gehrke 2008; Thomas 2001, 2003,), prepositions in Dutch (e.g. (12), Koopman 2000, den Dikken 2003, 2006, Gehrke 2008), dative marking prepositions in German (Gehrke 2008), and the locative $i$ preposition in Norwegian (e.g. (13), Tungseth 2006).

(11) a. ${ }^{\%}$ The boy walked in the store ${ }^{4}$

b. John run in the room

(12) Hij klimt in de stoel

He climbs in the chair

"He climbs in(to) the chair"

(13) Jens har syklet i grøfta.

Jens has biked in ditch.the

'Jens has biked in the ditch.' locative/directional

locative/directional

(English; from Gehrke, 2008)

locative/directional

(Dutch; from den Dikken, 2003)

locative / directional

(Norwegian; from Tungseth, 2006)

As shown succinctly by Gerhke (2008), locative prepositions allow directional readings only when certain conditions are met. First, directional readings are only possible in the complement position of a specific type of verb: the class of put-verbs, according to Levin's (1993) classification.

(14) a. Anna kicked the ball on/onto the table

(English)

b. John put the meat in/into the fridge

(15) Gert Jan schopte de bal op de tafel/de tafel op

(Dutch)

Gert Jan kicked the ball on the table

'Gert Jan kicked the ball on the table'

4. Nikitina (2008), Gehrke (2008), among others report that there is cross-speaker variation on the acceptability of these examples. It seems that directional interpretations of locative prepositions (such as in or on) are more easily accepted by American English speakers, than by British English ones, although in British English there are also cases of directional readings of locative prepositions with certain verbs, see for example Thomas (2001). As we will observe later on in the paper (section 2.3) we find a high degree of variation in the judgements across speakers in the different languages examined, both Germanic and Romance. See also den Dikken (2003, 2006) who reports similar data in Dutch. 
Among the predicates contained in the put-class, there are change of state verbs like break and directed motion verbs, like come or arrive. Moreover, there are verbs that are frequently classified as manner of motion verbs (such as walk, fly or run), even though they allow locative prepositions to be interpreted directionally. The examples below illustrate this phenomenon. ${ }^{5}$

(16) a. 'John came in the room

b. 'He went in the house

c. ?'Mum walked in the room

(from Thomas 2003)

Germanic goal of motion constructions with locative prepositions have specific syntactic properties: the preposition must appear in the verbal complement position, and stay VP internally and adjacent to the verb. The directional interpretation is lost whenever the PP moves out of VP, or when an adverb intervenes between the verb and the PP. This requirement is present in English (17), Dutch (18), and Norwegian (19).

(17) a. *In the house John run

b. *The pool in which John fell is extremely deep

(English, Gehrke 2008: 106)

In(18)a the PP can have a locative and a goal interpretation. However, if the $\mathrm{PP}$ is extraposed to the right as in (18)b only a locative reading is possible.

(18) a. ... dat hij onder de tafel kroop.

locative/directional that he under the table crawled

locative

'... that he was under the table and crawled.'

directional

'... that he crawled to a point under the table.'

locative/*directional

b. ... dat hij kroop onder de tafel. that he crawled under the table '... that he was under the table and crawled.' only locative reading

(Duth, Gehrke 2008: 108)

5. Note however that the examples are not plainly acceptable by all speakers and are subject to crossspeaker variation. In all three cases, even in the inherently directional ones, locative prepositions resist directional interpretations, and the appearance of a pure directional $\mathrm{P}$ improves the examples (compare (16) with (i)).

(i) a. John came into the room

b. He went into the house

c. Mum walked into the room 
The same phenomenon occurs in Norwegian, as shown by Tungseth (2006). In the examples below, preposition $i$ cannot be understood as a goal of motion when it is topicalized (19)a or clefted (19)b.

(19) a. I grøfta har Jens kjørt bilen.

locative/*directional in ditch.the has Jens driven

car.the 'In the ditch Jens drove the car.

b. Det er i grøfta (at) Jens har kjørt bilen. locative/*directional it is in ditch.the (that) Jens has driven car.the 'It is in the ditch (that) Jens has been driving the car.'

(Norwegian, Tungseth 2006: 43)

On the contrary, unambiguous directional prepositions like Eng. to, Nor. til, and Dt. naar give rise to a goal interpretation with any kind of motion verb. Moreover they need not to remain in a VP internal position ${ }^{6}$. These facts are observed in English, Norwegian and Dutch ${ }^{7}$.

(20) a. The pool into John fell is extremely deep

(English)

b. Into the room, John came

(21) Til supermarkedet har Jens aldri sprunget. to supermarket.the has Jens never run

'To the supermarket Jens has never run.'

(Norwegian)

(Tungseth 2006)

(22) naar het meer is Marjo gezwommen.

(Dutch)

To the lake is Marjo swum

'Marjo swam to the lake.'

6. In fact, unambiguous directional PPs can also occupy an adjunct position. As noted by Hoekstra (1984) and Gehrke (2008), among others, adjunct directional PPs always have an unbounded interpretation, as shown by auxiliary selection on perfective forms in Dutch, and therefore cannot be classified as goals. According to these authors, there are different attachment sites for directional PPs, and bounded directional interpretations are restricted to a non-adjunct syntactic position (see Gehrke 2008). Consequently, adjunct directional PPs are left outside the scope of this paper, in which I limit the analysis to bounded directional PPs, specifically, goals.

7. Dutch postpositions behave in that case as Dutch directional prepositions (see Gehrke 2008) in which they must also stay in a VP internal position. I will provide a possible analysis for these cases in next section, based on den Dikken's $(2003,2006)$ analysis, (see Gehrke 2008 for a different account).

(i) a. ... dat Jan op Ameland het bos in loopt. that Jan on Ameland the forest in runs

'... that Jan runs / is running into the woods on Ameland.'

b. *... dat Jan het bos in op Ameland loopt. 'that Jan the forest in on Ameland runs' 
As shown in this section, the properties that license directional readings for locative prepositions in Germanic languages are as follows:

1. the verbal meaning: verbs that are not very specific in their expression of manner and that semantically denote a change of location (Thomas 2003; Gehrke 2008).

2 . the position the PP occupies in the sentence.

In the next section I review similar examples in Romance languages. Some authors have considered these cases as counterexamples to Talmy's generalization. However, a closer look to the syntactic properties of these constructions and the study of their analogues in other linguistic families may help to clarify their true nature.

\subsection{Romance Prepositions}

Scholars like Folli (2002) and Son (2007) have argued that Romance languages do not allow for goal of motion constructions with manner of motion verbs because they lack pure directional prepositions ${ }^{8}$. This general observation is supported by the fact that simple Romance prepositions such as $a$, en/in in languages like French, Italian or Catalan, can appear with stative verbs (23)a and (23)b, and denote a spatial relation of location when they appear in an adjunct position (23)c.

(23) a. L'enfant est à la maison

(French)

the child is at home

'the child is at home'

b. Gianni è a casa di Maria

(Italian)

Gianni is at home of Mary

'Gianni is at Mary's house.'

c. L'home del barret cantava cada dia a l'estació. (Catalan)

The man of.the hat sung every day at the station

'The man with the hat was singing every day in the station'

8. Some authors have argued that the assumption that Romance languages do not have goal of motion constructions with manner verbs is false, and that directional prepositions of the until type, like Sp. hasta, Cat. fins $a$, It. fino $a$, or fr. jusqu'à are only directional, and henceforth can combine with any motion verb to derive goal of motion readings. However, the syntactic behavior of these prepositions seems different to Germanic pure directional ones in goal of motion constructions: (i) Romance until-phrases do not affect the aspectual content of the verbal predicate (Aske 1989) (Sp. Juan caminó hasta la cima durante dos horas/*en dos horas 'Juan walked until the summit for two hours/in two hours'); (ii) they do not establish a small clause configuration with the verbal subject, which is clearly observed in Italian, in which these prepositions do not trigger a change in auxiliary selection It. Gianni ha/*è camminato fino a casa 'Gianni walked until home'), and (iii) even if they seem to be in a VP-internal position (see or Folli and Ramchand 2005 or Fábregas 2007, Sp. Juan corrió al sótano,y *María lo hizo\{*al jardín/*hasta el jardín\} 'Juan ran to the cellar, and María did it (to the garden / until the garden), this position is more external than the one occupied by verbal complements (ie. they do not affect a change in aspectual interpretation or they do not trigger a change in auxiliary in Italian). For lack of space, I leave these examples out of the scope of the paper and I restrict myself to simple prepositions. 
However, authors like Zubizarreta and Oh (2007) or Demonte (2009), among others, have challenged the observation that Romance lacks pure directional prepositions, based on the behavior of Spanish preposition $a$. Spanish $a$ can not appear as the complement of a stative verb and it cannot express a static location even when combined with a non-motion predicate.

(24) a. *Juan está a casa.

(Spanish)

John is at home

'John is at home'

b. *Juan cantó a casa

John sang to home

Nevertheless, Fábregas (2007) shows that the preposition $a$ can have a locative meaning whenever the appropriate semantic relation between the figure and the ground is met. This author shows that the difference between Spanish $a$ and en also depends on the semantic properties of the relationship between the figure and the ground, and not only on the directional-locative distinction. As Fábregas (2007) points out locative $e n$ differs from preposition $a$ in that the former expresses a spatial relation where the figure is totally contained or supported by the ground (reminiscent to the central coincidence relation of Hale and Keyser 2002), while locative $a$ establishes a spatial relationship in which the figure is in contact with at least one point of the boundary of the ground, similar to the terminal coincidence relation in Hale and Keyser's terminology. For that reason, $a$ can combine with nouns that denote boundaries (e.g. lado 'side', borde 'border', limite 'limit', filo 'edge', etc.), points of a scale (e.g. principio, final, nivel), or some expressions in which the boundaries of the ground to which the figure is in contact are vague (e.g. estar al sol, estar al piano, etc.). Recall that in this case the concept of place and path does not correspond with Hale and Keyser's concepts of terminal and central coincidence. The examples below show that preposition $a$ can express locations when the appropriate semantic conditions are met.

(25) a. El ratón está al lado del libro.

(Spanish)

The mouse is at.the next of.the book

"The mouse is next to the book"

(Son 2007:152)

b. Juan está al sol.

(Spanish)

Juan is at.the sun

"Juan is standing in the sun"

c. Juan está al piano.

(Spanish)

Juan is at.the piano

"Juan is at the piano"

(Fábregas 2007)

Consequently, by the ESAH, if Spanish preposition $a$ can be interpreted as a locative preposition, the meaning of static location is basic, and the directional interpretation is contextually provided. In the next section I examine the conditions in which Romance prepositions appear in goal of motion constructions. 


\subsection{Locative prepositions in goal of motion constructions in Romance}

Simple prepositions in Romance languages have a directional interpretation when they appear in the complement position of an inherently directed motion verb.

(26) a. Juan entró en la habitación.

(Spanish)

Juan entered into the room

'Juan entered into the room'

b. Gianni è arrivato a casa.

(Italian)

Gianni is arrived at home

'Gianni has arrived home'

Furthermore, several authors (Fong and Poulin 1998; Folli 2002; Folli and Ramchand 2005; Zubizarreta and Oh 2007, among others) have studied cases where a manner of motion verb appears in a goal of motion construction. These cases have been observed mainly in Italian where the appearance of the auxiliary essere in perfective tenses makes the phenomenon more clear.

(27) a. Gianni è corso in spiaggia.

(Italian)

Gianni AUX.BE run in beach

'Gianni run in the beach'

b. La palla è rimbalzata dietro il tavolo.

(Italian)

The ball AUX.BE bounced behind the table

'The ball bounced behind the table'

Moreover, despite what has been argued by Zubizarreta and Oh (2007) or den Dikken (2008), Italian is not a special language in the Romance family. Thus, similar examples can be found in French, Catalan and Spanish.

(28) a. Ella corrió a la salida.

She ran to the exit

'She ran to the exit'

b. Le détective a bondi sur le gangster. the detective aux leap on the gangster.

"The detective has jumped on the gangster"

c. La noia va saltar a la piscina.

The girl aux jump to the swimming pool

'The girl jumped in the swimming pool locative/directional

(Spanish)

locative/directional

(French)

locative/directional

(Catalan)

As one can observe in the tables below, the set of motion verbs that combine with locative prepositions to derive a goal is limited and semantically similar in Romance and Germanic languages. Furthermore, there is great variation among the speakers regarding the acceptability of the examples in both linguistic families. 
Table 1. Romance Manner Verbs that allow goal of motion interpretations with locative Ps.

\begin{tabular}{|c|c|c|c|}
\hline Italian & Spanish & Catalan & French \\
\hline $\begin{array}{l}\text { correre 'run'; } \\
\text { rotolare 'roll'; } \\
\text { rimbalzare 'bounce'; } \\
\text { scivolare 'slide'; } \\
\text { gattonare 'crawl'; } \\
\text { saltare 'jump'; } \\
\text { volare 'fly'; } \\
\text { saltellare 'hop'. }\end{array}$ & $\begin{array}{l}\text { \%correr 'run'; } \\
\text { volar 'fly'; } \\
\text { saltar 'jump'; } \\
\text { \%caminar 'walk'; } \\
\text { conducir 'drive'; } \\
\text { rodar 'roll'. }\end{array}$ & $\begin{array}{l}\text { volar 'fly'; saltar } \\
\text { ‘jump'; rodolar } \\
\text { 'roll'; *conduir } \\
\text { ‘drive'; \%relliscar } \\
\text { ‘slid'; grimpar } \\
\text { 'climb' }\end{array}$ & $\begin{array}{l}\text { voler 'fly'; } \\
\text { sauter/bondir 'jump'; } \\
\text { rouler 'roll'; *marcher } \\
\text { 'walk'; *conduire } \\
\text { 'drive'; glisser 'slid'; } \\
\text { ramper 'crawl'; } \\
\text { grimper 'climb' }\end{array}$ \\
\hline
\end{tabular}

Table 2. Germanic Movement Verbs that allow goal of motion interpretations with locative prepositions.

\begin{tabular}{lll}
\hline English & Dutch & Norwegian \\
\hline run; walk; jump; roll; come & klimmen 'climb'; & falle 'to fall'; \% løpe 'run'; \\
& $\begin{array}{l}\text { wandeling 'walk'; springen } \\
\text { 'jump' }\end{array}$ & $\begin{array}{l}\text { sykle 'to bike'; hoppe } \\
\text { 'to jump'; rulle 'to roll' }\end{array}$ \\
\hline
\end{tabular}

The other property that characterizes Germanic goal of motion constructions with locatives Ps is the requirement that the locative PP stays in a local relation with the verb. Contrary to what happens in Germanic, Romance locative prepositions can be separated from the verb by adverbial material, and allow for topicalization and extraposition.

(29) a. L'oiseau a volé rapidement sur la fenêtre.

(French) the bird aux flown quickly on the window 'The bird flew quickly onto the window.'

b. Il a volé, l'oiseau, sur la fenêtre. he aux flown, the bird, on the window "The bird flew onto the window.'

The examples below show that sentences (30)a and (30)b denote a change of state/location, even though the PP is not adjacent to the verb.

(30) a. Juan resbaló de golpe al suelo. (Spanish) Juan slipped of knock to.the floor 'Juan suddenly slipped to the floor'

b. El barril rodó, sin embargo, al pie de la colina. the barrel rolled, nevertheless, to.the botton of the hill 'Nevertheless, the barrel rolled down the hill.'

Likewise in Catalan, the PP can appear clefted or separated from the verb by adverbial material, preserving the goal of motion interpretation. 
(31) a. El Joan salta sempre que pot a la piscina.

(Catalan)

The Joan jump always that can to the swimming.pool 'Joan jump whenever he can into the swimming pool.'

b. Les monedes van rodolar, tot d'una, a terra.

the coins aux roll all of one to floor

'the coins rolled suddenly onto the floor'

Contrary to Demonte (2009), these PPs are not in an adjunct position as shown by the difference in the choice of auxiliary in Italian, VP topicalization and do-so substitution. As in the Germanic cases, the locative PP is in a VP internal nonadjunct position, but unlike Germanic examples, the PP is movable and need not remain VP internally.

(32) a. Maria è/ *a corsa nel bosco.

(Italian)

Maria is/have run in.the wood

'Maria has run into the wood.'

b. La rana è/*a saltellata nella trappola.

The frog is/have jumped in the trap

'The frog has jumped into the trap.'

(33) a. 'Correr a casa es lo que Juan hizo para no llegar tarde.

(Spanish)

run to home is what that Juan did for not arrive late

"Run home is what John did to not arrive late"

b. Juan saltó a la piscina y *María lo hizo al estanque.

Juan jumped into the swimming.pool and María cl did to the reservoir

'Juan jumped into the swimming pool and María did so into the reservoir.'

As shown in this section, Germanic and Romance goal of motion constructions with locative PPs exhibit similar properties with regards to the type of motion verb they appear with. However, Germanic languages prefer the use of pure directional prepositions in goal of motion constructions, even with pure inherent directed motion verbs. In Romance, inherent directed motion verbs can combine with simple Ps without restrictions. Finally, locative PPs behave differently in Romance and Germanic: Romance locative prepositions can be moved freely preserving the goal of motion reading, whereas Germanic ones cannot. In the following two sections I propose a theory to explain the derivation of goal of motion constructions with Germanic and Romance PPs, in order to shed some light on the aforementioned distinction between satellite and verb-framed languages.

\section{An analysis of PPs in Romance and Germanic languages}

In this section, I provide an analysis of Romance prepositions following den Dikken's (2003, 2006) theory of adpositions, as outlined in section 1.1 above. This section 
aims to determine which of the four previously mentioned possible structures correspond with Romance prepositions and with goal of motion structures seen so far. Recall that there are two basic types of structures: type I, in which the verb takes a defective/bare directional $\mathrm{P}$ as its complement, and type II in which the verb is merged with a complete directional PP.

(34) Type I: $\left.V \Gamma_{\underline{P P}} \underline{P}_{\underline{D I R}} \ldots\right]$

a. $\mathrm{V}\left[_{\mathrm{PP}} \mathrm{P}_{\mathrm{DIR}}\left[{ }_{\mathrm{PP}} \mathrm{P}_{\mathrm{LOC}} \mathrm{DP}\right]\right]$

b. $\mathrm{V}\left[_{\mathrm{PP}} \mathrm{P}_{\mathrm{DIR}}\left[{ }_{\mathrm{CP}} \mathrm{C}^{[\mathrm{PLACE}]} \ldots\left[_{\mathrm{PP}} \mathrm{P}_{\mathrm{LOC}} \mathrm{DP}\right]\right]\right]$

(35) Type II: $\left.V L_{C P} \underline{C}^{[P A T H]} \ldots L_{P P} \underline{P}_{D I R} \ldots\right]$

a. $\mathrm{V}\left[_{\mathrm{CP}} \mathrm{C}^{[\mathrm{PATH}]} \ldots\left[_{\mathrm{PP}} \mathrm{P}_{\mathrm{DIR}}\left[_{\mathrm{PP}} \mathrm{P}_{\mathrm{LOC}} \mathrm{DP}\right]\right]\right]$

b. $\mathrm{V}\left[{ }_{\mathrm{CP}} \mathrm{C}^{[\mathrm{PATH}]} \ldots\left[_{\mathrm{PP}} \mathrm{P}_{\mathrm{DIR}}\left[{ }_{\mathrm{CP}} \mathrm{C}^{[\mathrm{PLACE}]} \ldots\left[_{\mathrm{PP}} \mathrm{P}_{\mathrm{LOC}} \mathrm{DP}\right]\right]\right]\right]$

This section is structured as follows: first, section 3.1 reviews the first type of prepositional structures depicted above, namely, bare directional prepositions that appear in the verbal complement position. Next, section 3.2 overviews structures of type II in which directional $\mathrm{P}$ is not defective and projects a full-fledge phrase. Finally, section 3.3 states overall conclusions.

\subsection{Type I: defective PPS}

A careful consideration of first type structures points out two possibilities, according to the kind of locative PP that the directional preposition takes as its complement. Then, in the first structure (Ia), the bare directional preposition selects a bare locative $\mathrm{P}$. The structure forces incorporation of the $\mathrm{P}_{\mathrm{LOC}}$ head into $\mathrm{P}_{\mathrm{DIR}}$, and further movement of the DP complement into the specifier of the $\mathrm{P}_{\mathrm{DIR}}$ and $\mathrm{P}_{\mathrm{LOC}}$ complex, resulting in a postpositional order, according to den Dikken (2003, 2006).

(36) $\mathrm{V}\left[_{\mathrm{PP}}\left[\mathrm{DP}_{\mathrm{i}}\right]\left[\mathrm{P}_{\mathrm{DIR}}-\mathrm{P}_{\mathrm{LOC}}\left[\left[_{\mathrm{PP}}<\mathrm{P}_{\mathrm{LOC}}>[<\mathrm{DP}\rangle_{\mathrm{i}}\right]\right]\right]\right]$

As assumed in Koopman (2000) for a constituent to be movable it needs to project a complete functional projection up to the $\mathrm{CP}$ head. As correctly predicted by the analysis, Dutch postpositions cannot move ${ }^{9}$.

9. However den Dikken 2006 points out cases in which postpositions can be topicalized without losing the directional meaning (i).Den Dikken (2006) establishes that postpositions can be generated from two different structures. Cases like (i), therefore, correspond with a structure where a directional $\mathrm{P}$ has an extended projection on its own.

(i) [de boom in] is Jan geklommen the tree in is Jan climbed 
(37) *Ze zijn gelopen het bos in. they are walked the forest in (intended meaning: 'They walked into the forest.')

(Gehrke 2008:250)

In Dutch postpositions, therefore, the bare directional preposition gets licensed from below. The bare locative preposition bans incorporation of $\mathrm{P}_{\mathrm{DIR}}$ into $\mathrm{V}$ and allows manner incorporation, namely, root adjunction into the verb. Consequently, Dutch postpositions allow for the presence of any manner of motion in a directed motion event expression.

(38) $\left.\mathrm{V}-\mathrm{R}\left[_{\mathrm{PP}}\left[\mathrm{DP}_{\mathrm{i}}\right]\left[\mathrm{P}_{\mathrm{DIR}}-\mathrm{P}_{\mathrm{LOC}}\left[_{\mathrm{PP}}<\mathrm{P}_{\mathrm{LOC}}>[<\mathrm{DP}\rangle_{\mathrm{i}}\right]\right]\right]\right]$

(39) Brigit dansde het podium op.

Brigit danced the stage on

'Brigit danced onto the stage.'

According to den Dikken $(2003,2006)$ structures of type (Ia) always yield a postpositional order, since it would enforce overt raising of $\mathrm{P}_{\text {LOC }}$ into $\mathrm{P}_{\text {DIR }}$, forcing movement of the DP into the specifier of $\mathrm{P}_{\mathrm{DIR}}$. However, it is not clear to me why movement of the DP is obligatory in these cases. In this paper, I consider the possibility that DP movement is only optional and that $\mathrm{P}_{\mathrm{LOC}}$ does not always incorporate into $\mathrm{P}_{\text {DIR }}$, allowing $\mathrm{P}_{\text {DIR }}$ to incorporate into V. According to this analysis, defective $\mathrm{P}_{\text {LOC }}$ does not move and $\mathrm{P}_{\text {DIR }}$ incorporates into $\mathrm{V}$ resulting in a prepositional order. $\mathrm{P}_{\text {LOC }}$ would be bare and hence not movable. This structure could explain Dutch directional prepositional cases and ambiguous PPs in English and Norwegian, explaining the restriction imposed by the semantics of the verb into the distribution of ambiguous PPs.

Previous analysis to locative PPs in goal of motion constructions in Germanic, such as Gehrke (2008) and Tungseth (2006), establish that the directional interpretation of these locative prepositions is PP-external. Specifically, locative PPs receive a directional interpretation from a specific functional head, PredP in Gehrke's (2008) proposal, or ResP in Tungseth's (2006) (which I consider to be equivalent for the purposes of this discussion), which is associated with an incremental chain interpretation (Rohstein 2004; see Gehrke 2008). The syntactic properties of Germanic locative PPs in directed motion events are explained structurally. For Gehrke (2008), movement of locative PPs out of the VP is impossible, as it would imply movement of Pred'. Instead, movement of pure directional PPs implies movement of the whole PP from the complement position of the verb. Nevertheless, these analyses face different problems. First, lack of movement of the PP does not follow from their analyses. Assuming an eventive approach such as the one assumed in these works, following Ramchand (2008), which establishes that arguments receive their thematic interpretation structurally, Tungseth argues that locative PPs only receive a directional interpretation in the complement position of a ResP, and that this interpretation is lost if the relation between the verb and the locative PP is disrupted by intervention of an adverb or by movement of the PP. As Tungseth (2006: 59) points out, 
there is no explanation in this type of theory as to whether movement of the PP is not allowed for locative Ps since it is not evident what would preclude reconstruction in these cases. In both theories, we should explain why movement of locative PP plus reconstruction is ruled out from the complement position of the Pred/Res head, or why movement of PredP/ResP is not a possibility either in Gerhke's system or Tungseth's, something that does no receive a principled explanation in these works.

Second, if Romance counterexamples to Talmy's typology imply the combination of locative Ps with verbs that contain a resultative feature in their semantic interpretation, and thus have the same structure as the Germanic constructions of the verb-framed type discussed before, then we have to explain why Romance languages allow free movement of the alleged locative PP, or why PP-movement is possible in some languages and not in others. Therefore, Gehrke's and Tungseth's proposal does not offer a conclusive analysis of the constructions examined here. Moreover, their analysis would fail to explain the differences in the syntactic properties of directed motion events across languages.

Romance does not have postpositions to derive directional readings, ${ }^{10}$ which makes type (Ia) unattested in this linguistic family. Moreover, in the case that it would allow a prepositional order, type (Ia) would predict that the PP is not movable, contrary to fact. Structure of type (IIb) seems to be a good candidate to instantiate goal of motion expressions like the ones described in section 2. In this structure repeated here in (40), $\mathrm{P}_{\mathrm{LOC}}$ cannot incorporate into $\mathrm{P}_{\mathrm{DIR}}$, due to minimality restrictions. Note that successive movement of $\mathrm{P}_{\mathrm{LOC}}$ up to $\mathrm{P}_{\mathrm{DIR}}$ is banned by Li's 1990 condition on head movement (see section 1).

(40) $\left.\left.\left.\mathrm{V}_{[\mathrm{PP}} \mathrm{P}_{\mathrm{DIR}}\left[_{\mathrm{CP}} \mathrm{C}^{[\mathrm{PLACE}]}\left[\ldots{ }_{\mathrm{PP}} \mathrm{P}_{\mathrm{LOC}} \mathrm{DP}\right]\right]\right]\right]\right]$

The fact that locative PPs project a full fledged structure explains why PPs are movable in Romance and do not exhibit locality restrictions. Along the lines of Mateu and Rigau's (2002) analysis, movement of $\mathrm{P}_{\mathrm{DIR}}$ into the aspectual light verb prevents root insertion into V, following Talmy's intuition (among others) that the expression of manner and path in the verbal head are mutually exclusive. Here, manner incorporation is understood as the insertion of a root into the verbal head, and is prevented by Kayne's condition on adjunction (Kayne 1994) (see also den Dikken 2008 for a similar approach). The structure of (41), where V appears with an adjoined root, yields an ungrammatical structure since null $\mathrm{P}_{\mathrm{DIR}}$ gets unlicensed.

$$
* \mathrm{~V}-\mathrm{R}-\mathrm{P}_{\mathrm{DIR}}\left[\mathrm{PP}<\mathrm{P}_{\mathrm{DIR}}>\ldots\right]
$$

10. I leave outside of the paper the analysis of postpositions of the type Cat. muntanya amunt "up the mountain" or riu avall "down the river" (Sp. calle arriba 'up the street'). Even if it is true that these postpositions have a directional meaning, they cannot form goal of motion constructions: they do not denote the final location of a change of location predicate. Note that these structures do not change the aspectual interpretation of the event Cat. "Vaig caminar muntanya amunt durant dues hores/*en dues hores" ('I walked up the mountain for two hours'). Furthermore, the structure of these elements seems to be more complex than the prepositions object of my study. See Pérez Saldanya and Rigau (2005) for an analysis of these constructions. 
To sum up, we have seen that Germanic and Romance locative PPs in goal of motion constructions can be analyzed in a principled way that covers the restrictions outlined in the previous section, summarized here in (42) and (43).

(42) Locative PPs in Germanic languages receive a goal reading depending on: $\checkmark$ The verbal type

$\checkmark$ The position of the PP with regard to the verb

(43) Locative PPs in Romance languages receive a goal reading depending on: $\checkmark$ The verbal type

$x$ The position of the PP with regard to the verb.

The first condition on locative PPs that receive a goal reading is explained for both linguistic families: in both families there is incorporation of $\mathrm{P}_{\mathrm{DIR}}$ into the verb, yielding similar effects on the type of verb that can appear in these constructions, and on the correlation between manner specificity and resultativity observed by different authors (see for example Thomas 2001, 2003):

(44) *V- R- $\mathrm{P}_{\mathrm{DIR}}\left[{ }_{\mathrm{PP}}<\mathrm{P}_{\mathrm{DIR}}>\ldots\right]$

The second condition is explained by taking into account the properties of locative PPs: in Romance locative PPs are always complete, while in Germanic languages they are bare, and hence defective, banning the movement of the PP, and adverbial intervention.

(45) Romance locative PPs in directed motion events

$$
\left.\mathrm{V}-\mathrm{P}_{\mathrm{DIR}}\left[_{\mathrm{PP}}<\mathrm{P}_{\mathrm{DIR}}>\left[_{\mathrm{CP}} \mathrm{C}^{[\mathrm{PLACE}]}\left[\ldots\left[_{\mathrm{PP}} \mathrm{P}_{\mathrm{LOC}} \mathrm{DP}\right]\right]\right]\right]\right]
$$

(46) Germanic locative PPs in directed motion events $\mathrm{V}-\mathrm{P}_{\mathrm{DIR}}\left[_{\mathrm{PP}}<\mathrm{P}_{\mathrm{DIR}}>\left[_{\mathrm{PP}} \mathrm{P}_{\mathrm{LOC}} \mathrm{DP}\right]\right]$

As seen in this section, both Germanic and Romance locative PPs can have a directional interpretation whenever they appear with a restricted set of verbs, whose meaning is similar across languages (see section 2). On this account, there would exist cases where certain roots can lexicalize the $\mathrm{V}+\mathrm{P}_{\mathrm{DIR}}$ complex head. These roots would be conceptually unspecified and allow directional content to be present into their meaning. ${ }^{11}$ As seen in previous section, both Germanic and Romance languages show the same restriction with respect to the verbal type, but differ on the syntactic properties of PP: while Germanic PPs must be adjacent to the verb Romance PPs are movable and can be separated from the verb by adverbial material. This structural difference is explained by this account.

11. The structure outlined so far, however, seems incompatible with the view that defective heads do not receive a phonological interpretation by its own. One possibility would be to consider preposition in not to be the lexical instantiation of $\mathrm{P}_{\mathrm{LOC}}$. Rather it could be base generated in other position as a kind of modifier. I will leave this possibility open for further discussion. 
The next section explores the type II structure, where the directional preposition projects a full-fledge phrase when appearing in the complement position of V. I will endorse a view in which satellite-framed languages are characterized by having a complete $\mathrm{P}_{\mathrm{DIR}}$, thus preventing incorporation of $\mathrm{P}$ into $\mathrm{V}$ and allowing manner incorporation to occur. I will explore some properties of these structures in Germanic languages.

\subsection{Type II: complete PPs}

In this section the paper discusses structures of type II in relation to Germanic constructions. As seen previously, defective directional Ps (type I) correspond with either Dutch postpositions, Germanic ambiguous PPs, or Romance directed motion constructions. The former case is the only one that allows manner incorporation since defective directional $\mathrm{P}$ need not incorporate into the verb as it gets licensed from below, via incorporation of $\mathrm{P}_{\mathrm{LOC}}$ into $\mathrm{P}_{\mathrm{DIR}}$. The rest corresponds to the verbframed type and precludes adjunction of the root due to prior incorporation of $\mathrm{P}_{\mathrm{DIR}}$ into $\mathrm{V}$.

In this section I explore Germanic goal of motion constructions with pure directional PPs, assuming that they have a structure of type II. Pure directional prepositions in Germanic languages instantiate a complete $\mathrm{PP}_{\mathrm{DIR}}$. Accordingly, manner incorporation and movement of the PP follows from this account. According to Gehrke (2008) and Tungseth (2007), pure directional prepositions have these properties in Norwegian, English and Dutch.

(47) PP topicalization and clefting is possible

a. Til supermarkedet har Jens aldri sprunget.

(Norwegian, Tungseth to supermarket.the has Jens never run 2006:62)

'To the supermarket Jens has never run.'

b. naar het meer is Marjo gezwommen.

To the lake is Marjo swum

'Marjo swam to the lake.'

c. The pool into which John John fell is extremely deep. (English,

Thomas 2001)

(48) Pure directional prepositions can combine with manner of motion verbs

a. Jens danset til stua.

Jens danced to living.room.the

'Jens danced to the living room.'

b. The boat floated to the shore

c. Marjo is naar het meer gezwommen.

Marjo is to the lake swum

'Marjo swam to the lake.'
(Norwegian, Tungseth 2006:60)

(English)

(Dutch) 
Manner incorporation is possible in these languages since directional PPs are complete and get licensed within. Moreover, these PPs are independent and movable:

(49) $\mathrm{V}-\mathrm{R}\left[{ }_{\mathrm{CP}} \mathrm{C}^{[\mathrm{PATH}]} \ldots\left[_{\mathrm{PP}} \mathrm{P}_{\mathrm{DIR}}[\ldots]\right]\right]$

Therefore, pure directional prepositions correspond to second type structures, explaining why directional Ps have the syntactic properties discussed so far. Within type II structures, there are two possibilities depending on the size of the functional structure below $\mathrm{P}_{\mathrm{DIR}}$ and projected by $\mathrm{P}_{\mathrm{LOC}}$ a full functional structure or a defective one. In the first case, $\mathrm{P}_{\mathrm{DIR}}$ located within a complete $\mathrm{CP}^{[\mathrm{PATH}]}$, needs to be licensed by lexical insertion, since $\mathrm{P}_{\text {LOC }}$ cannot move up to $\mathrm{P}_{\text {DIR }}$. Furthermore, $\mathrm{P}_{\text {LOC }}$ must also be licensed by the same mechanism. This kind of structure would give rise to a sentence where both the directional and the locative preposition are independent and movable. I leave for further research whether or not there is any possible instantiation of this structure within Germanic languages ${ }^{12}$. As seen in this section, there will be cases of bare $\mathrm{P}_{\mathrm{DIR}}$ in Germanic languages as well, instantiated by Dutch postpositions or, marginally, by verb-framed type structures in English, Norwegian or by Dutch prepositions. However, bare $\mathrm{P}_{\mathrm{DIR}}$ is not common in Germanic languages since pure directional PPs are always preferred, even with motion verbs that do not express manner.

\subsection{Summary of the approach}

In this section I have addressed an analysis of Romance and Germanic goal of motion constructions with locative PPs. It has been proposed that Romance goal of motion constructions have a prepositional structure based on type Ib: directional $\mathrm{P}$ incorporates into the verb and locative PP becomes the complement of the whole V-P complex. Movement behavior of locative PPs in Romance is explained by this analysis as well. On the other hand, Germanic locative PPs are better explained by the type Ia structure, which also corresponds to Dutch postpositions. Finally, I have explored pure directional Ps as an instantiation of structure of type IIa, explaining why pure directional PPs move freely.

In conclusion, the analysis can explain why Germanic and Romance are different in regards to the movement behavior of locative $\mathrm{P}$ in goal of motion constructions. Finally, the account given here explains why, in Germanic and Romance cases, the semantic properties of the verb influence the availability of directional interpretations of locative Ps: these interpretations always involve incorporation of the directional P into the verb. In the next section I propose an analysis of the

12. However I suspect that $P_{\text {LOC }}$ in this linguistic family is always bare, and therefore type (Ib) is unattested in these languages. Therefore, the difference between Germanic and Romance could be stated in terms of completeness or defectiveness of certain heads: Germanic languages can be characterized as having a complete $\mathrm{P}_{\text {DIR }}$ and a bare $\mathrm{P}_{\text {LOC }}$, while Romance languages would have reverse scenario, a bare $\mathrm{P}_{\mathrm{DIR}}$ and a complete $\mathrm{P}_{\text {LOC }}$. I leave for further consideration an approach on these terms. 
set of verbs that appear in Romance goal of motion constructions in the context of a microparametric approach to linguistic variation.

\section{Towards an analysis of satellite-framed/verb-framed distinction}

The analysis of locative prepositions outlined here explains why locative prepositions derive directional readings under certain conditions. On this account, the specific properties of adpositions (Svenonius 2004, cf. Den Dikken 2008, Folli 2002, Gehrke 2008, Tungseth 2006) have consequences in the verbal domain, yielding the effect that the licensing of a locative $\mathrm{P}$ in a goal of motion construction is only available for a specific set of manner of motion verbs, both in Romance and Germanic. This issue leads to the relation between manner and path in the verbal domain.

Despite similarities, there is a difference in the availability of goal of motion constructions with locative prepositions in both linguistic families. Romance's unique way of forming inherent motion events is by using simple locative Ps whereas Germanic locative PPs are marginal in goal of motion constructions, even with inherent directional verbs. Thus, Germanic motion verbs prefer directional Ps to express directed movement (e.g. Eng. 'John came in the room vs. John came into the room), irrespective of the manner specification in the verb. Recall that from the analysis depicted here, directional Ps in complement position in Germanic ${ }^{13}$ cases project a full-fledged functional structure, which prevents directional Ps from incorporating into the verb, contrary to what happens in the Romance case. However, there is space for variation in Germanic languages in which directional $\mathrm{P}_{\mathrm{DIR}}$ can be marginally bare, yielding a verb-framed structure. Romance and Germanic goal of motion constructions with locative PPs exhibit similar properties: they are restricted to a set of verbs that is semantically akin across languages and show a high degree of variability and instability in the acceptability judgments across speakers. These facts seem to point towards a unified approach to these counterexamples in both linguistic families (cf. Zubizarreta and Oh 2007).

Previous approaches to Talmy's generalization counterexamples put forward the existence of two different types of manner verbs. According to these proposals, there are verbs that express path and manner simultaneously. For instance, Folli (2002) considers that verbs like correre include an optative resultative feature in their lexical entry. The account put forth here, however, allows certain manner verbs to contain a directional meaning without having to endorse multiple lexical entries. Thus, I consider that certain roots that are conceptually unspecific can lexicalize the $\mathrm{V}+\mathrm{P}$ complex. On this account, the absence of manner specification (Thomas 2001, 2003) attested in Germanic and Romance's verb-framed structured is explained: a bare directional preposition that is not licensed from below needs to incorporate into the verb, yielding the semantic effects noted by Folli (2002) and sev-

13. This is true except for Dutch postpositions thatare bare directional PPs, as we have seen. Recall that in these cases incorporation of $\mathrm{P}_{\mathrm{LOC}}$ into $\mathrm{P}_{\mathrm{DIR}}$ prevents $\mathrm{P}_{\mathrm{DIR}}$ incorporation into the verb. 
eral others. In Romance, bareness of directional $\mathrm{P}$ forces the root to always lexicalize a $\mathrm{V}+\mathrm{P}$ complex, while in Germanic $\mathrm{P}$ incorporation does not occur with pure directional PPs, and the root can lexicalize only V.

Thus, in Romance, even if manner and path seem to be included at the same time, the path component is more prominent than the manner one. As pointed out by Jones (1983), and reported by Thomas (2003), the ability of French prepositions $\grave{a}$, sur, and dans "to indicate goal depend on two factors that are related to the verb: firstly, the verb must express directional movement and secondly, it must express little, if anything concerning manner of motion" (Thomas 2003: 121). Jones (1983) notes that the difference between the set of verbs that does not allow directional readings of locative Ps in French, like marcher 'walk', and the verbs that do allow them, like ramper "crawl" or even gambader "scamper,", is based on the absence or presence of a path component included in the meaning, rather than by the specificity of the manner content (see Zubizarreta and Oh 2007, for a similar intuition).

(50) L'enfant a rampé sous le lit locative $/ \%$ directional The child aux crawl under the bed "The child crawled under the bed"

(51) La jeune fille a gambadé derrière la maison locative $/ \%$ directional The girl aux scamped behind the house "The girl scamped behind the house"

Similarly Mateu and Rigau analyze verb-particle constructions of the type found in Italian and other Romance languages like the ones in (52) (see Mateu and Rigau 2008, 2010 and references cited therein):

(52) buttare giù 'throw down', uscire fuori 'exit out', correre via 'run away', tirare su 'bring up', lavare via 'wash away', etc.

These authors propose that these constructions are not cases of satellite-framed structures as English phrasal verbs. Instead, there is a path component present in the meaning of the verb and the satellite repeats the information already contained in the verbal predicate. Mateu and Rigau's (2002) analysis of inherent motion verbs entrar 'go into' is also based on this assumption: in the sentence el noi va entrar a l'habitació 'the boy entered into the room', the PP is a kind of cognate path. In my analysis I do not analyze these Ps as cognate paths since I am assuming that simple Romance PPs lexicalize the locative portion of the PP. However, I agree with the idea that Romance strongly requires verbs that contain the meaning of path to form goal of motion constructions, irrespective of the presence of the manner component. ${ }^{14}$ Crucial to Mateu and Rigau's theory, even if these verbs seem

14. Specifically, Mateu and Rigau (2010) analyze Italian particle verbs as verbs that do not specify manner of motion, since the root generates as the ground of the directional preposition and conflates into the verb throughout the directional preposition. In this paper I do not commit with the specific syntactic location of the root in these structures. 
to express manner, structurally they do not because, in their theoretical terms, there is no manner incorporation. In this approach, I espouse a similar view to Mateu and Rigau in the theoretical conception of manner incorporation, which is seen as the adjunction of a root into the verbal light head, something that is precluded if a $\mathrm{P}$ has already been adjoined.

Nevertheless, I depart from previous accounts that follow a parametric approach to lexicalization patterns in terms of how this distinction is specified across languages. In Mateu and Rigau's (2002) approach, the satellite/verb-framed distinction relies on the presence/absence of different 1-syntactic rules among languages, an Incorporation and a Conflation/Compounding rule; or in Snyder's (1995) terms, in the presence of a positive/negative setting of a compounding parameter (Gehrke 2008, Zubizarreta and Oh 2007, among others). Instead, in this paper's approach, the existence of Path or manner incorporation depends on the specific properties of prepositional heads in these languages. A defective $\mathrm{P}_{\mathrm{DIR}}$ can force $\mathrm{P}$ incorporation into $\mathrm{V}$ as a way to license the structure. $\mathrm{P}$ movement into $\mathrm{V}$ precludes manner incorporation, yielding the effect that manner of motion verbs cannot appear in verb-framed structures. On the contrary, the projection of a complete $\mathrm{P}_{\mathrm{DIR}}$ allows the verb and the preposition to be independent constituents, allowing root adjunction into the verb. From this perspective, the satellite/verb-framed distinction is reduced to specific properties of lexical heads. This account differs from previous ones in that Talmy's lexicalization patterns are not the consequence of the availability of certain syntactic or morphological rules in a given language. Rather, the unavailability of certain syntactic operations is a consequence of the specific featural content (defective or non-defective) of lexical heads.

This paper, then, establishes a theoretical account of the manner-path correlation observed previously in the literature (Jones 1983, Levin 1993, Mateu and Rigau 2002, Talmy 2000, Thomas 2003). Verb-framed structures both in Germanic and Romance with manner of motion verbs are marginal and restricted to a specific set of verbs. The theoretical distinction between conceptual semantics and syntactic-semantics ${ }^{15}$ might be used to explain why the semantics behind the set of verbs that participate in these structures is restricted and similar across languages. Furthermore, the fact that there is great cross-speaker variation in acceptability judgments in very different languages, reminiscent to Sorace's (2000) facts on auxiliary selection, may suggest that the question at hand is not one of grammaticality, but rather a question of deviance and failure at the interfaces. Here, I will assume that verbs are the conjunction of roots and syntactic structures into which the root gets inserted. From this point of view, certain roots are unspecified and can lexicalize a $\mathrm{V}+\mathrm{P}$ complex; the semantic construal provided at the interface mixed with the conceptual semantics of the root yields deviant or undeviant sentences. Therefore, the acceptability judgments of these constructions are not very strong and are subject to coercion. 


\section{Conclusions}

Talmy's classification states that languages vary according to how they lexicalize a motion event. Satellite-framed languages lexicalize manner in the verb and path in a satellite, while verb-framed languages lexicalize the path in the verb, and express the manner via an adjunct. This paper explains this distinction focusing on the particular properties of prepositions across languages. Specifically I establish that Romance directional PPs are always bare in the complement position of the verb, forcing incorporation of the directional preposition and preventing manner incorporation, since adjunction of the root to the complex V-P is disallowed by Kayne's (1994) condition on adjunction. The structure of (54) with an adjoined root will yield an ungrammatical structure since $\mathrm{P}_{\mathrm{DIR}}$ would get unlicensed. In this paper, I have argued that in Germanic the structure in (55) will be a well-formed sentence, since $\mathrm{P}_{\mathrm{DIR}}$ gets licensed internally and incorporation into the verb is not forced. As a consequence, manner incorporation, that is, root adjunction into the aspectual light verb, can take place.

(53) $\left.\left.\mathrm{V}\left[_{\mathrm{PP}} \mathrm{P}_{\mathrm{DIR}}\left[\left[_{\mathrm{CP}} \mathrm{C}^{[\mathrm{PLACE}]} \ldots\left[_{\mathrm{PP}} \mathrm{P}_{\mathrm{LOC}} \mathrm{DP}\right]\right]\right]\right]\right]\right]$

(54) *V- R- $\mathrm{P}_{\mathrm{DIR}}\left[\mathrm{PP}_{\mathrm{PP}}<\mathrm{P}_{\mathrm{DIR}}>\ldots\right]$

(55) V-R $\left.\left.\left[{ }_{\mathrm{CP}} \mathrm{C}^{[\mathrm{PATH}]} \ldots\left[_{\mathrm{PP}} \mathrm{P}_{\mathrm{DIR}} \ldots\right]\right]\right]\right]$

Furthermore, the paper explores a cross-linguistic difference in the behavior of locative prepositions in goal of motion constructions between Germanic and Romance: while directional readings of locative Germanic prepositions require a strong local verbal relation (Thomas 2001, Gehrke 2008, Tungseth 2006), Romance locative prepositions can move freely, preserving directional readings. In this paper I attribute this effect to the properties of locative prepositions in these two linguistic families: in Romance locative prepositions are complete, while in the Germanic languages studied in this work they are bare.

The proposal put forth here aims to relate empirical observation on Romance prepositions (Son 2007, Fábregas 2007) with manner incorporation accounts (Mateu and Rigau 2002, den Dikken 2008). In this account, I put forth a theory of cross-linguistic variation based on a microparametric view (Borer 1984, also den Dikken 2008, Mateu and Rigau 2002, Son 2007, among others): differences in the expression of motion events can be can be accounted for by noting the specification of syntactic features within lexical heads.

\section{References}

Aske, Jon (1989). «Path predicates in English and Spanish: A closer look». In: Hall, K.; Meacham, M.; Shapiro, R. (eds.). Proceedings of the Fifteenth Annual Meeting of the Berkeley Linguistics Society. Berkeley, CA: Berkeley Linguistics Society, pp. 1-14.

Borer, Hagit (1984). Parametric Syntax. Dordrecht: Foris. 
Borer, Hagit (2005). Structuring sense II: The normal course of events. Oxford; New York: Oxford University Press.

Cummins, Sarah (1996). «Movement and direction in French and English». Toronto Working Papers in Linguistics 15: 31-54.

Demonte, Violeta (2009). «La Construcción de los eventos de movimiento en español. La dirección y la manera de movimiento». Talk given in the VII Congreso Internacional de Lingüística Hispánica, University of Leipzig, Germany. Unpublished manuscript.

Dikken, Marcel den (2003). «On the syntax of locative and directional adpositional phrases». CUNY Graduate Center (earlier version of Den Dikken 2006), unpublished manuscript.

Dikken, Marcel den (2006). «On the functional structure of locative and directional PPs». In: Cinque, Guglielmo; Rizzi, Luigi (eds). The cartography of prepositional phrases. Oxford/New York: Oxford University Press, pp. 74-126.

Dikken, Marcel den (2008). «Directions from the GET-Go: On the syntax of manner-ofmotion verbs in directional constructions». CUNY Graduate Center: unpublished manuscript.

Fábregas, Antonio (2007). «The exhaustive lexicalization principle». Troms $\phi$ Working Papers on Language and Linguistics: Nordlyd 34.2.

Folli, Raffaella (2002). Constructing Telicity in English and Italian. University of Oxford, doctoral dissertation.

Folli, Raffaella; Ramchand, Gillian (2005). «Prepositions and results in Italian and English: Analysis from event decomposition». In: Verkuyl, H.; de Swart, H.; van Hout, A. Perspectives on Aspect. Dordrecht: Springer, pp. 81-105.

Fong,Vivienne; Poulin, Christine (1998). «Locating linguistic variation in semantic templates». In: Koenig, Jean-Pierre. Discourse and Cognition: Bridging the Gap. Stanford: CSLI Publications, pp. 29-39.

Gehrke, Berit (2007). «On directional readings of locative prepositions». In: Blaho, Sylvia; Schoorlemmer, Erik; Vicente, Luis (eds.) Proceedings of ConSOLE XIV, pp. 99-120.

Gehrke, Berit (2008). Ps in motion: On the semantics and syntax of P elements and motion verbs. Utrecht University, doctoral dissertation.

Hale, Ken; Keyser, Samuel Jay (2002). Prolegomenon to a Theory of Argument Structure. Linguistic Inquiry Monographs 39. Cambridge, MA: MIT Press.

Hoekstra, Teun (1984). Transitivity: Grammatical Relations in Government and Binding Theory. Dordrecht: Foris.

Jackendoff, Ray (1990). Semantic structures. Cambridge, MA: MIT Press.

Jones, Michael. A. (1983) «Speculations on the expression of movement in French». In: Durand, Jacques (ed.). A Festschrift for Peter Wexler. University of Essex, pp. 305-354.

Kayne, Richard (1994). The antisymmetry of syntax. Cambridge, MA: MIT Press.

Koopman, Hilda (2000). «Prepositions, postpositions, circumpositions, and particles». In: Koopman, H. (ed.). The Syntax of Specifiers and Heads. London: Routledge, pp. 204-260.

Levin, Beth (1993). English verb classes and alternations: A preliminary investigation. Chicago: University of Chicago Press.

Li, Yafei (1990). « $\mathrm{X}^{0}$-binding and verb incorporation». Linguistic Inquiry 21: 399-426. 
Mateu, Jaume (2001). «Small Clause Results Revisited». In: Zhang, N. (ed.). ZAS Papers in Linguistics, vol. 26. ZAS, Berlin.

Mateu, Jaume (2002). Argument structure. Relational construal at the syntax-semantics interface. Universitat Autònoma de Barcelona, doctoral dissertation.

Mateu, Jaume (2008). «On the 1-syntax of directionality/resultativity: The case of Germanic preverbs». In Asbury, A.; Dotlacil, J.; Gehrke, B.; Nouwen, R. (eds.). Syntax and semantics of spatial P. Amsterdam: John Benjamins, pp. 221-50.

Mateu, Jaume; Rigau, Gemma (2002). «A minimalist account of conflation processes: Parametric variation at the lexicon-syntax interface». In: Alexiadou, Artemis (ed.). Theoretical Approaches to Universals. Amsterdam: John Benjamins, pp. 211-236.

Mateu, Jaume; Rigau, Gemma (2008). «Romance Paths as cognate complements: a lexical-syntactic account». In: Masullo, P.; O’Rourke, E.; Huang, C. (eds.). Romance Linguistics 2007: Selected Papers From The 37th Linguistic Symposium On Romance Languages (LSRL). Amsterdam: John Benjamins, pp. 227-241.

Mateu, Jaume; Rigau, Gemma (2010). «Verb-particle constructions in Romance: A lexical-syntactic account». Probus 22 (2): 241-269.

Nikitina, Tatiana (2008). «Pragmatic factors and variation in the expression of spatial goals: the case of into vs. in» In: Asbury, Anna; Dotlačil, Jakub; Gehrke, Berit; Nouwen, Rick (eds.). Syntax and Semantics of Spatial P. Amsterdam: John Benjamins, pp. 175-195.

Ramchand, Gillian (2008). Verb Meaning and the Lexicon: A First-Phase Syntax. Cambridge Studies in Linguistics, Cambridge University Press.

Son, Minjeong (2007). «Directionality and Resultativity: The Cross-linguistic Correlation Revisited». Nordlyd 34.2: 126-164.

Svenonius, Peter (2004). Spatial Ps in English. Troms $\varnothing$ University, unpublished manuscript.

Svenonius, Peter (2006). «The emergence of axial parts». Nordlyd 33: 1-22.

Talmy, Leonard (2000). Toward a Cognitive Semantics. Cambridge, MA: MIT Press.

Thomas, Emma (2001). «On the expression of directional movement in English». Essex Graduate Student Papers in Language and Linguistics IV: 87-104.

Thomas, Emma (2003). «Manner specificity as a factor in the acceptance of in and on in directional context». Essex Graduate Student Papers in Language and Linguistics V, pp. 117-146.

Tortora, Christina (2008). «Aspect inside PLACE PP». In: Asbury, Anna; Dotlačil, Jakub; Gehrke, Berit; Nouwen, Rick (eds.), Syntax and semantics of spatial P. Amsterdam: John Benjamins, pp. 221-50.

Tungseth, Mae (2006). Verbal Prepositions in Norwegian: Paths, Places and Possession. Troms $\varnothing$ University, doctoral dissertation.

Riemsdijk, Henk. van (1978). A case study in syntactic markedness. Dordrecht: Foris.

Riemsdijk, Henk van (1990). «Functional prepositions». In: Pinkster, H.; Gene, I. (eds.). Unity in Diversity. Foris: Dordrecht, pp. 229-241.

Zubizarreta, María Luisa; Oh, Eunjeong (2007). On the Syntactic Composition of Manner and Motion. Linguistic Inquiry Monographs. Cambridge, MA: The MIT Press. 